\title{
Determinants of Export Performance among Small to Medium Enterprises in Zimbabwe
}

\author{
Roseline Tapuwa Karambakuwa ${ }^{1}$ and Ronney M Ncwadi ${ }^{2}$ \\ ${ }^{1}$ Department of Economics, Bindura University of Science Education, \\ P. Bag 1020, Bindura Zimbabwe \\ ${ }^{2}$ Department of Economics, Nelson Mandela University, P.O. Box 77000, \\ Port Elizabeth, 6031, South Africa \\ E-mail: ${ }^{1<\text { rkarambakuwa@gmail.com }>,{ }^{2}<\text { Ronney.Ncwadi@nmmu.ac.za }>}$
}

KEYWORDS Gravity. Markets. Inflation. Growth. Imports

\begin{abstract}
Small to medium enterprises (SMEs) export performance is important in Zimbabwe as the country needs increased exports from all sectors to reduce external trade deficit. The paper pertains the determinants of export performance among SMEs in Zimbabwe. Despite SME export promotion efforts by government, the export performance by the SMEs has been below expectation. A sample consisting of 120 exporting SMEs was engaged for primary data. The researchers also employed secondary data. Econometric regression was carried out using the gravity model of trade while estimation was done using the random effects method. The conclusion from the study was that the following variables determine export performance of SMEs; business ownership, export processing zones (EPZs), export years, firm size, gross domestic product of trading partner and distance from trading partner. Both the government and SMEs need to consider these variables for successful SME export support programs.
\end{abstract}

\section{INTRODUCTION}

Small business export growth is essential for the development of economies with limited capital, since SMEs are a means through which accelerated economic growth and rapid industrialisation can be achieved (Harris and Gibson 2006). In Zimbabwe, government participation in SME export support has increased in the past few years, as is evidenced by the creation of the Ministry of Small to Medium Enterprises, among other initiatives (Irwin 2011). Even though there has been support for SMEs, they have failed to increase their exports significantly to play their part in reducing Zimbabwe's perpetual trade deficit over the years.

In Zimbabwe, exporting SMEs have been operating in an environment characterised by decreased export competitiveness, and increased uncertainty. Historically, the country's export performance deteriorated over the years as the country suffered from macroeconomic instabilities, got isolated from major trading partners and suffered from hyperinflation during the period building up to 2009. The inflation was

Address for correspondence:

Karambakuwa Roseline Tapuwa

Telephone: +263772772091

E-mail: rkarambakuwa@gmail.com caused by seigniorage and this led to the emergence of the black market for foreign exchange (Makochekanwa 2007). A study by McIndoeCalder (2017) indicates that during the inflation period in Zimbabwe, prices were driven by increases in the money supply rather than by changes in price setting behaviour. High inflation led to a significant fall in exports and increase in trade deficit.

In 2009 the country abandoned the local currency, Zimbabwe dollar, and adopted a multicurrency system dominated by the US dollar, effectively ending high inflation. However, the economic performance of the country remained depressed, with no significant growth in exports thereafter. The SMEs new challenge was exporting from an environment in which the major currency in use, the US dollar, was stronger than the currencies of most trade partners, and the effect was to make Zimbabwe's goods with major trade partners expensive and uncompetitive. The situation was worsened by the high cost of production in Zimbabwe. All these factors also affected large companies. The general decline in export capacity, coupled with high imports, increased Zimbabwe's trade deficit worsening the trade deficit as shown on Table 1.

With reference to Table 1, Zimbabwe experienced trade deficit from 2008 to 2016 . The country recorded a reduction in trade deficit in 2012 
Table 1: Zimbabwe's merchandise trade 2008-2016 (US\$ million)

\begin{tabular}{lrrrrrrrrr}
\hline & 2008 & 2009 & 2010 & 2011 & 2012 & 2013 & 2014 & 2015 & 2016 \\
\hline Exports & 2200 & 2269 & 3199 & 3512 & 3882 & 3507 & 3064 & 2704 & 2837 \\
Imports & 2950 & 2900 & 3800 & 4400 & 4400 & 4300 & 4200 & 4000 & 3700 \\
Trade Balance & -750 & -631 & -601 & -888 & -518 & -793 & -1136 & -1296 & -863 \\
\hline
\end{tabular}

Source: Data extracted from World Trade Organisation (WTO) Time Series Data (2016)

but it worsened from 2013 onwards such that it stood at almost US\$1.3 billion by the end of 2015 . However, the trade deficit narrowed in 2016. To come up with policies that reduce this trade deficit it becomes important to understand what determines improved export performance for Zimbabwe. The next paragraphs therefore give an analysis of empirical literature on determinants of export performance in different countries.

Reis and Forte (2016) indicate that a firm's export performance in Portugal is determined by some industry characteristics namely labour productivity, export orientation and concentration, as well as firm characteristics in the form of labour productivity, and the size and age of the firm. However, results of the correlation analysis by Quansah and Bunyaminu (2017) indicated that the age of the firm and the numbers of employees working for the firm are negatively correlated to export performance. Freund et al. (2016) estimated simple gravity regression and found that variation in trade costs across markets affects SME exporters in a very similar way to large firms. For SME export performance to improve, the SMEs need technical assistance in the areas of quality management and productivity improvement so that they comply with product standards and regulations applied in export markets (UNCTAD 2001). Maurel (2009) concluded that export commitment, export competencies and producing region are significantly and positively related to export performance.

Findings in South American countries by Oura et al. (2016) indicate that international experience has a greater impact on export performance of SMEs. This concurs with findings by Edwards et al. (2018) that firms that import and export consistently demonstrate premiums in terms of productivity, employment, wages and capital intensity in production compared to firms that do not trade. However, Lengler et al. (2015) suggests that technological intensity and competitive intensity are the key determinants of success in an export market while Manamba
(2016) suggest that economic real per capita GDP, trade liberalization, and exchange rate have a positive impact on export performance in Tanzania.

Pradhan and Zohair (2015) analysed two selected states in India and found out that differential performance in manufacturing exports can be related to the states' contrasting heterogeneity in terms of economic development, infrastructure, skill, knowledge and sub national policies. Further, Gupta et al. (2015) explored the determinants of exports of IT companies of India and the results showed that world demand and real effective exchange rate affected company exports. To analyse Bangladesh trade flows with its trading partners, Rahman (2004) applied a generalised gravity model and the study concluded that Bangladesh's trade was positively determined by openness of trade, size of economies and per capita GDP differential of trading countries. Bangladesh' trade was negatively affected by transportation costs. Finally, institutional environment factors such as government policies, procedures and regulations can lessen the influence of entrepreneurial orientation and networking capabilities on SMEs' export performance (Ajayi 2016).

\section{Objective}

The paper seeks to establish the determinants of export performance among SMEs in Zimbabwe, using export intensity as a measure of export performance. It is important to establish the determinants of SME export performance in Zimbabwe to ensure that the right export promotion initiatives are implemented and that the desired results are achieved in the form of export growth.

\section{MATERIAL AND METHODS}

The hypothesis underlying the paper is that variables under study do not determine the ex- 
port performance of SMEs in Zimbabwe. The quantitative research design was used with combined use of both primary and secondary data the period 2009 to 2016. The gravity model of trade was applied, using random effects panel data. Panel data was preferred as, over time it controls for heterogeneity and it enables monitoring of possible unobservable specific individual effects, thereby removing the problem of biased estimates in the event of correlation. Panel data also contains more degrees of freedom and more sample variability than cross-sectional data, hence improving the efficiency and accuracy of econometric estimates (Hsiao 2006).

The sample consisted of 120 exporting SMEs from three provinces in Zimbabwe, namely Harare, Mashonaland Central and Mashonaland East, selected using convenient non-probability sampling method. Administration of questionnaires and interviews on the SMEs ensured that primary data was collected more scientifically and objectively. Secondary data was retrieved from the SMEs records and from the websites of the World Trade Organisation (WTO) and Zimbabwe National Statistics Agency (ZIMSTATS).

Overwhelmingly, the gravity model of trade has been applied to aggregate level data (including sectoral data). The paper makes a significant contribution to empirical literature on gravity model as the model is applies to micro level data on a primarily macro setting. The use of micro level data was necessary because it is very difficult in Zimbabwe to obtain aggregate data specifically on SME exports. The gravity model of trade specifies that volume of trade between two countries is proportional to their economic sizes or in-comes and is inversely related to geographical distance between the countries. Tinbergen (1962) and Pöyhönen (1963) first applied the gravity model to assess and analyse international trade flows. The basic gravity model is specified as follows:

$$
\operatorname{Trp}=\frac{\alpha\left(\mathrm{Y}_{\mathrm{r}} \mathrm{Y}_{\mathrm{p}}\right) \beta^{1}}{\left(\text { Dist }_{\mathrm{rp}}\right) \beta^{2}}
$$

Where $r \# p$

$\operatorname{Trp}$ - shows total merchandise between country $r$ and $p$

$Y_{r}$ - Country r's national income

$\mathrm{Y}_{\mathrm{p}}-$ Country p's national income Dist $_{r p}$ - Distance between country r and p's commercial centres.

$\beta_{1}$ is expected to be positive. Y, a country's income, is expected to be positive, since high $\mathrm{Y}$ means higher ability to produce and export. Dis- tance is another determinant of bilateral trade between country $r$ and country $p$ and it represents transport costs. $\beta_{2}$ is expected to be negative since it is a coefficient of trans-port costs which are a factor resistant to trade. The three basic gravity model variables in the estimated gravity model are Zimbabwe's GDP and the trading partner's GDP, which were both expected to have a positive relationship with export performance, and distance, which was expected to have a negative relationship with export performance.

Augmenting the gravity model with the proper variables is crucial to obtain better estimates and reduce the effect of omitted variable bias. The augmented gravity model includes other variables accounting for additional factors that may affect SME export intensity namely; export processing zones, years of education, exporting years, the firm's age, its size, gender, product type, support institutions and business ownership. Some of the variables in the augmented gravity model are presented in the log-linear form to allow for the interpretation of coefficients as elasticities. According to Gelman and Hill (2007), the coefficients on the natural log scale are directly interpretable as approximate proportional differences. Regression was done on the panel data for the period 2009 to 2016. The dependent variable, export intensity of SMEs in Zimbabwe is calculated as shown in equation 2.

$$
\text { Export intensity }=\frac{\text { Export Sales }}{\text { Total Sales }} \times \frac{100}{1}
$$

The gravity model is therefore specified as follows;

Export Intensitity $_{\mathrm{it}}=\beta_{0}+\beta_{1}$ (Institutions $\left._{\mathrm{it}}\right)+\beta_{2} \quad\left(\right.$ Ownership $\left._{\mathrm{it}}\right)$ $+\beta_{3}\left(\right.$ Education $\left._{\mathrm{it}}\right)+\beta_{4}\left(\right.$ EPZs $\left._{\mathrm{it}}\right)+\beta_{5}\left(\right.$ ExportYears $\left._{\mathrm{it}}\right)+\beta_{6}$ $\left(\right.$ ProductType $\left._{i t}\right)+\beta_{7} \quad\left(\right.$ FirmAge $\left._{\mathrm{it}}\right)+\beta_{8} \quad\left(\right.$ FirmSize $\left._{\mathrm{it}}\right)+\beta_{9}$ $\left(\right.$ InDistance $\left._{\mathrm{it}}\right)+\beta_{10}\left(\right.$ InGDP $\left._{\mathrm{it}}\right)+\beta_{11}\left(\left(\right.\right.$ InGDPZimm $\left._{\mathrm{it}}\right)+\mathrm{U}_{\mathrm{it}}$

The Durbin-Wu-Hausman test was carried out to determine whether to use fixed or random effects estimation. The following is the hypothesis for the test:

$H_{0}: \alpha_{i}$ are distributed independently of $X_{j}$

$H_{A}: \alpha_{i}$ are not distributed independently of

If the null hypothesis is not rejected, then both random and fixed effects are consistent but fixed effects is inefficient as it involves estimating unnecessary dummy variable coefficients (Dougherty 2014). Results from the Durbin-WuHausman Test showed a probability value of 1 , indicating failure to reject the null hypothesis. 
Since the null hypothesis is not rejected, both random and fixed effects are consistent, but fixed effects is inefficient as it involves estimating unnecessary dummy variable coefficients (Dougherty 2014). The econometric gravity model was therefore estimated using non- dynamic panel data OLS with random effects. The e- views 8 statistical software was used to analyse data.

Instead of treating as fixed, the assumption is that it is a random variable with a mean value of . Thus, the intercept value of an SME can be expressed as follows:

$$
\beta_{1 i}=\beta_{1}+\varepsilon_{1}=1,2 \ldots ., N
$$

where is a random error term with mean value zero and variance. The SMEs have a common mean value for the intercept and the individual intercept values for each company are reflected in the error term (Gujarati 2005).

Given the equation

$Y_{\text {it }}=\beta_{1 i}+\beta_{2} X_{2 \text { it }}+\beta_{3} X_{3 i t}+\mathrm{u}_{2 \text { it }}$

Substituting 4 into 5 the following random effects equations are obtained:

$$
\begin{aligned}
& Y_{i t}=\beta_{1}+\beta_{2} X_{2 i t}+\beta_{3} X_{3 i t}+\ldots+\beta_{k} X_{\text {kit }}+\varepsilon_{\mathrm{t}}+u_{i t} \\
& =\beta_{1}+\beta_{2} X_{2 i t}+\beta_{3} X_{3 i t}+\ldots+\beta_{k} X_{\text {kit }}+w_{i t} \\
& + \text { Where } w_{i t}=\varepsilon_{t}+u_{i t}
\end{aligned}
$$

is an error term with two components: , the individual specific error component and, the combined time series and cross-section/individual-specific components. The following assumptions must hold if the estimator is efficient:

$$
\begin{gathered}
\varepsilon_{i} \sim N\left(0, \sigma_{\varepsilon}^{2}\right) \\
u_{i t} \sim N\left(0, \sigma_{u}^{2}\right) \\
E\left(\varepsilon_{i} u_{i t}\right)=0 \quad E\left(\varepsilon_{i} \varepsilon_{j}\right)=0 \quad(i \neq j) \\
E\left(u_{i t} u_{i s}\right)=E\left(u_{i t} u_{j t}\right)=E\left(u_{i t} u_{j s}\right)=0 \quad(i \neq j ;(t \neq s)
\end{gathered}
$$

The individual error components are not correlated with each other and are not auto correlated across both cross-section and time series units. From the assumptions in (8), it follows that;

$E\left(w_{i t}\right)=0 \quad$ and $\quad \operatorname{var}\left(w_{i t}\right)=\sigma_{\varepsilon}^{2}+\sigma_{u}^{2}$

This is a crucial assumption of the random effects model.

\section{RESULTS}

The following variables are statistically significant in determining SME export performance in Zimbabwe; business ownership, EPZ experi- ence, export years, firm size, distance from trading partner and GDP of trading partner. Thus, the null hypothesis for the above-mentioned variables is rejected and a conclusion is made that the variables determine export performance of SMEs in Zimbabwe. The findings of the paper indicate that most of the significant variables namely business ownership, EPZ, export years, firm size and GDP of trading partner have positive coefficients implying that they can improve export performance of SMEs in Zimbabwe if considered in policy making. However, distance has a negative coefficient implying that the greater the distance the less the exports. Distance therefore reduces export performance of SMEs.

The paper findings suggest that SMEs that have a history of having previously operated in EPZs export more than SMEs that never operated in EPZs, suggesting that the EPZs have played a vital role in SME export promotion in Zimbabwe. Export experience in the form of export years also increases export performance, hence the longer the SME has been exporting the higher the exports the SME is likely to have. Further, the size of the firm, measured by the number of employees also positively determines export performance of SMEs implying that the larger the firm, the higher the export performance. The paper findings also suggest a positive and significant relationship between trading partner's GDP and exports by the Zimbabwean SMEs, as GDP growth in the trading partner country create more export opportunities for the SMEs.

\section{DISCUSSION}

One of the paper's findings is that increased distance between Zimbabwe and the trading partner's country reduces export performance of Zimbabwe's SMEs due to increased transport cost. The same can be said for Bangladesh from findings by Rahman (2004) who concluded that Bangladesh' trade was negatively affected by transportation costs, among other variables. Exporting to regional markets that are closer to Zimbabwe can help ensure improved export performance of SMEs. Further, EPZ's, representing government export commitment have played a vital role in ensuring SME export growth in Zimbabwe. This finding concurs with Maurel (2009) who found out that that export commitment is 
positively related to export performance. Hence based on these findings, the introduction of special economic zones in Zimbabwe in 2017 is likely to lead to increased SME export performance. The finding that export experience increases export performance imply that the SMEs with international experience are aware of what is needed to be able to be competitive in the export markets, hence they need to be supported. This result is supported by findings by Oura et al. (2016), that international experience has a greater impact on export performance of SMEs than innovation capacity.

The size of the firm positively determines export performance since with more employees, SMEs can implement division of labour and specialisation, which leads to increased production and economies of scale, hence increased exports. The findings concur with results from a study by Reis and Forte (2016), which indicated that a firm's export performance is positively determined by size of the firm among other variables. However, contrary to this finding, Quansah and Bunyaminu (2017) indicated that the numbers of employees working for the firm are negatively correlated to export performance. Another finding is that the trading partner's GDP positively determines SME export performance and this suggests that as much as interventions in foreign economies are beyond its economic scope, Zimbabwe benefits from improved economic performance of its trading partners.

\section{CONCLUSION}

The paper sought to find out the factors determining SME export growth in Zimbabwe. The gravity model of trade was used for econometric regression and estimation was done using the random effects method. The conclusion from the paper is that SME export performance can be improved by considering the following aspects; business ownership, EPZ, export years, firm size, and GDP of trading partner. SME export performance can be reduced by increased distance from trading partner, hence it is necessary to utilise exports markets that are nearer. EPZs have played a vital role in export promotion in Zimbabwe and the government can ensure increased SME exports by intensifying and expanding the current special economic zones. If owners are encouraged to run their SME businesses themselves rather than delegating most of the work, it will help to reduce unnecessary bureaucracy and ensure timely decision making leading to increased SME exports.

Further, experience in the form of export years also increase export performance, hence the longer the SME has been exporting the higher the exports by the SME. The size of the firm, measured by the number of employees determines export intensity of SMEs as the larger the firm, the higher the export intensity. Hence, export support which targets larger, experienced SMEs are likely to yield higher results in the form of increased exports. The GDP of trading partner's country is also an important consideration because the results from the paper have shown that as the GDP increases, exports by the Zimbabwean SMEs to the country also increase. Hence, it makes sense for government to facilitate trade links between the SMEs and partners in mostly growing economies.

\section{RECOMMENDATIONS}

There are several recommendations from this paper. Of importance is the need to create the right environment and circumstances to motivate and stimulate SME owners and managers in Zimbabwe to increase export capacity. This can be achieved through making export opportunities easily available to the SMEs. Nearer export markets need to be promoted by the government for the SMEs since they are cheaper to export to. The government needs to revive bilateral trade arrangements with such nearby countries and introduce some export incentives for exporters which may cushion the exporters in terms of transport cost. Pertaining regional economic integration, Zimbabwe needs to increase trade links with countries whose economies are growing as GDP of trade partner is positively related to SME exports. This can be done through entering into trade agreements to secure SME exports in these countries.

Since larger SMEs have better capacity to export, export support programs should prioritise these larger SMEs with more labour for increased productivity, economies of scale and efficiency in operation. This would ultimately lead to improved export performance and reduction in cost of production per unit. Improved export performance can be achieved when SME owners prioritise managing businesses themselves or fully delegate their managers to make 
timely decisions that are critical to the performance of the businesses. Finally, since the results from this paper have shown that operating within an EPZ can increase exports it is better for the government to intensify the implementation of special economic zones which were introduced in 2017, which are similar to EPZs.

\section{REFERENCES}

Ajayi B 2016. The impact of entrepreneurial orientation and networking capabilities on the export performance of Nigerian agricultural SMEs. Journal of Entrepreneurship and Innovation in Emerging Economies, 2(1): 1-23.

Dougherty SM 2014. Introduction to Econometrics. $4^{\text {th }}$ Edition. Great Britain: Oxford University Press.

Edwards L, Sanfillippo M, Sundaram A 2018. Importing and firm export performance: New evidence from South Africa. South African Journal of Economics, 86(S1): 79-95.

Freund C, Hufbauer GC, Jung E 2016. Enhancing Export Opportunities for Small and Medium-Sized Enterprises. Policy Brief 16-17. USA: Peterson Institute for International Economics.

Gelman A, Hill JG 2007. Data Analysis using Regression and Multilevel/Hierarchical Models. Cambridge, NY: Cambridge University Press.

Gujarati DN 2005. Basic Econometrics. International Edition. New York: McGraw-Hill Higher Education.

Gupta SD, Raychaudhuri A, Haldar SK 2015. Determinants of exports of information technology in India: An empirical analysis. South Asia Economic Journal, 16(1): 64-81.

Harris ML, Gibson SG 2006. Determining the common problems of early growth of small businesses in Eastern North Carolina. SAM Advanced Management Journal, 71(2): 39-45.

Hsiao C 2006. Panel Data Analysis, Advantages and Challenges. IEPR Working Paper 06.49. Institute of Economic Policy Research, University of Southern California

Irwin D 2011. Learning from business support in Africa. Management Research Review, 34(2): 207-220.

Lengler JFB, Sousa CMP, Perin UKM, Gattermann S, Hoffmann C, Martínez-López FJ 2015. The antecedents of export performance of Brazilian small and medium-sized enterprises (SMEs): The non-linear effects of customer orientation. International Small Business Journal, 34(5): 701-727.
Makochekanwa A 2007. A Dynamic Enquiry into the Causes of Hyperinflation in Zimbabwe. Working $\mathrm{Pa}$ per 2007-10. South Africa: University of Pretoria.

Manamba E 2016. Determinants of export performance in Tanzania. Journal of Economics Library, 3(3): 470-487.

Maurel C 2009. Determinants of export performance in French wine SMEs. International Journal of Wine Business Research, 21(2): 118-142.

McIndoe-Calder T 2017. Hyperinflation in Zimbabwe: Money demand, seigniorage and aid shocks. Journal of Applied Economics, 50(15): 1659-1675.

Oura MM, Zilber SN, Lopes EL 2016. Innovation ca-pacity, international experience and export performance of SMEs in Brazil. International Business Review, 25(4): 921-932.

Pöyhönen P 1963. A tentative model for the volume of trade between countries. Weltwirtschaftliches Archive, 90: 93-99.

Pradhan JP, Zohair M 2015. Subnational export performance and determinants: Evidence from two Indian states. Review of Market Integration, 7(2): 133174.

Quansah F, Bunyaminu A 2017. Firm internal factors and export performance in the Ghanaian wood industry. International Journal of Business and Social Science, 8(2): 174-180.

Rahman MM 2004. The Determinants of Bangladesh's Trade: Evidence from the Generalised Gravity Model. The Economic Society of Australia's 33, Conference of Economists. University of Sydney, NSW 2006, Australia.

Reis J, Forte R 2016. The impact of industry characteristics on firms' export intensity. International Area Studies Review, 19(3): 266-281.

Tinbergen J 1962. Shaping the World Economy: Suggestions for an International Economic Policy. New York: The Twentieth Century Fund.

United Nations Conference on Trade and Development (UNCTAD) 2001. Best Practices in Financial Innovations for SMEs. Background Paper Presented at the Intergovernmental Expert Meeting on Improving the Competitiveness of SMEs in Developing Countries: The Role of Finance to Enhance Enterprise Development, 22-24 October, Geneva.

World Trade Organisation Statistical Database 2016. From <www.wto.org > (Retrieved on 4 February 2016).

Paper received for publication on August 2017

Paper accepted for publication on December 2017 